\title{
Aplikasi Matlab Pada Peralatan Pengaman Sidik Jari Menggunakan Sensor C3
}

\author{
Priyatno $^{1}$, Muhammad Yanuwar ${ }^{2}$ \\ ${ }^{1}$ Universitas Ma'arif Nahdatul Ulama, Kebumen (Teknik Informatika, Fapertek, UMNU) \\ ${ }^{2}$ Universitas Ma'arif Nahdatul Ulama, Kebumen (Teknik Informatika, Fapertek, UMNU) \\ priyatnojenggala@gmail.com ${ }^{1}$,yanuwarmuhammad@gmail.com ${ }^{2}$
}

\begin{abstract}
The tools used in fingerprint-based door locks are now easier. Related to the times and the current era of global progress, several methods have been developed that are used to create fingerprint door-based security devices. Every human fingerprint is a unique one based on the process of embryo formation. This study was used to determine the door security components using fingerprints. The process carried out is fingerprint input, identification and verification of each fingerprint recorded in the data.
\end{abstract}

Keywords: Sensor C3, Arduino Uno ATmega 328P

\begin{abstract}
Abstrak
Peralatan yang digunakan pada kunci pintu berbasis sidik jari kini lebih mudah. Terkait dengan perkembangan zaman dan era kemajuan global saat ini telah berkembang beberapa metode yang digunakan untuk membuat perangkat keamanan berbasis pintu sidik jari. Setiap sidik jari manusia adalah salah satu keunikan berdasarkan proses pembentukan embrio. Penelitian ini digunakan untuk mengetahui komponen pengaman pintu dengan menggunakan sidik jari. Proses yang dilakukan adalah input sidik jari, identifikasi hingga verifikasi setiap sidik jari yang terekam di database.
\end{abstract}

Kata kunci: Sensor C3, Arduino Uno ATmega 328P

\section{Pendahuluan}

Peralatan yang digunakan dalam sistem biometrik telah berkembang pesat terutama untuk teknologi keamanan karena dapat memenuhi dua fungsi yaitu identifikasi dan verifikasi. Biometri memiliki ciri-ciri tidak dapat hilang, tidak dapat dilupakan dan tidak mudah dipalsukan. Keberadaannya melekat pada manusia, yang satu dengan yang lainnya tidak akan sama, sehingga keunikannya lebih terjamin. Sistem yang paling banyak digunakan adalah sistem sidik jari dengan mengenali pola sidik jari. Pola sidik jari memiliki tingkat keamanan yang tinggi, sistem ini banyak digunakan di perkantoran, perusahaan, sekolah, pemerintahan, rumah sakit. Selain memiliki tingkat keamanan yang tinggi, sistem pola sidik jari ini juga mudah digunakan.

Pengamanan pintu menggunakan sistem biometrik sebagai pengaman masih jarang. Sebagian besar keamanan di Indonesia masih menggunakan kunci manual, jika kunci hilang maka butuh waktu untuk bisa membukanya. Saat menggunakan sidik jari, salah satu jari kita akan menjadi kunci tanpa efek yang terlupakan atau tertinggal di suatu tempat. Di pasaran memang sudah banyak dijual peralatan yang menggunakan sistem biometrik, namun yang paling banyak adalah sidik jari. Apabila menggunakan sidik jari, salah satu jari kita akan menjadi kunci tanpa efek terlupakan atau tertinggal di suatu tempat. Di pasaran sudah banyak dijual peralatan yang menggunakan sistem biometri, akan tetapi kebanyakan adalah presensi sidik jari.

Sidik jari memiliki suatu orientasi dan struktur periodik berupa komposisi dari garis-garis gelap dari kulit yang naik (ridges) dan garis-garis terang dari kulit yang turun (furrows) yang berliku-liku membentuk suatu pola yang berbeda-beda. Walaupun garis-garis alur tangan terbentuk berbedabeda, tetapi sifat-sifat khusus dari sidik jari yang disebut dengan minutiae adalah unik untuk setiap individu. Ciri-ciri ini membentuk pola khusus yang terdiri dari terminasi atau percabangan dari alur. Untuk memeriksa apakah dua sidik jari berasal dari jari yang sama atau bukan, para ahli mendeteksi minutiae tersebut. Sistem Identifikasi Sidik Jari Otomatis (AFIS) akan mengambil dan membandingkan ciri-ciri tersebut untuk menentukan suatu kecocokan.

Dermatoglifi atau pola sidik jari didefinisikan sebagai gambaran sulur-sulur dermal yang pararel pada jari-jari tangan dan kaki, serta telapak tangan dan telapak kaki. Secara anatomis dermatoglifi akan membuat permukaan kasar pada telapak tangan jari 
tangan, telapak kaki, dan jari kaki yang berfungsi dalam membantu proses memegang atau berpijak sehingga tidak tergelincir. Pembentukan dermatoglifi dimulai dengan proliferasi sel epitel basal epidermis volar pad sekitar minggu ke-10 sampai minggu ke-11 kehamilan. Sel-sel kemudian membentuk lipatan-lipatan dan menjadi rigi episermis.

\subsection{Bentuk Pokok Sidik Jari}

Ada tiga bentuk sidik jari yaitu busur (arch), sangkutan (loop), dan lingkaran (whorl). Bentuk pokok tersebut terbagi lagi menjadi beberapaa subgroup yaitu bentuk busur terbagi menjadi plain arch dan tented arch, bentuk sangkutan terbagi menjadi Ulnar loop dan Radial loop, sedangkan bentuk lingkaran terbagi menjadi Plain whorl, Central pocket loop whorl, Double loop whorl dan Accidental whorl. Perbedaan utama dari ketiga bentuk pokok tersebut terletak pada keberadaan core dan delta pada lukisan sidik jarinya. Loop (Sangkuatan) adalah bentuk pokok sidik jari dimana satu garis atau lebih datang dari satu sisi lukisan, melereng, menyentuh atau melintasi suatu garis bayangan yang ditarik antara delta dan core, berhenti atau cenderung berhenti kearah sisi semula. Syaratsyarat (ketentuan) Loop:

1. Mempunyai sebuah delta.

2. Mempunyai sebuah core.

3. Ada garis melengkung yang cukup.

4. Mempunyai bilangan garis (Ridge Counting)

Bentuk loop terdiri dari 2 jenis, yaitu: ulnar loop : garisnya memasuki pokok lukisan dari sisi yang searah dengan kelingking, melengkung ditengah pokok lukisan dan kembali atau cenderung kembali ke arah sisi semula. Dan radial loop : garisnya memasuki pokok lukisan dari sisi yang searah dengan jempol, melengkung di tengah pokok lukisan dan kembali atau cenderung kembali ke arah sisi semula.

\subsection{Arch (Busur)}

Arch merupakan bentuk pokok sidik jari yang semua garis-garisnya datang dari satu sisi lukisan, mengalir atau cenderung mengalir ke sisi yang lain dari lukisan itu, dengan bergelombang naik ditengah-tengah. Arch terdiri dari:

1. Plain Arch adalah bentuk pokok sidik jari dimana garis-garis dating dari sisi lukisan yang satu mengalir ke arah sisi yang lain, dengan sedikit bergelombang naik ditengah.

2. Tented arch (Tiang Busur) adalah bentuk pokok sidik jari yang memiliki garis tegak (upthrust) atau sudut (angle) atau dua atau tiga ketentuan loop.

Dari penelitian sebelumnya yang dilakukan dengan judul Implementasi Wavecom Pada
Pemantau Beban Listrik Berbasis Mikrokontroler adalah membuat suatu alat yang dilengkapi dengan sensor arus, sensor tegangan mikrokontroler AT328 dan menggunakan modul wavecom 1306B sebagai penghubung yang dapat meneruskan data ke telepon melalui sms dengan format yang telah ditentukan perangkat lunak Ide Arduino pada tahun 2017 [1]. Aplikasi Absensi Siswa Menggunakan Sidik Jari di SMA Negeri 9 Manado dilakukan [2]. Kemampuan Pendengaran Penyu Berdasarkan Penilaian Sinyal ABR [3]. Pengaturan Pengalihan Event Yang Tepat Secara Cepat Berbasis Mikrokontroler AT89C2051 [4]. Pola Sidik Jari Anak Down Syndrome di SLB Bakhti Kencana dan Anak Normal di SD Budi Mulia Dua Yogyakarta dibuat [5]. Prototipe Arduino Uno ATMega Automatic Fan Based Activator 328 dengan Fingerprint [6]. Mencakup tinjauan pustaka dan memuat unsur latar belakang, permasalahan/rumusan masalah, tujuan dan manfaat penelitian, hipotesis bila ada dapat dicantumkan, dan rancangan penelitian.

\section{Metodologi Penelitian}

UML (Unified Modeling Language) admin mendaftarkan user atau pengguna untuk direkam dalam pendaftaran sidik jari, kemudian mikrokontroler melakukan verifikasi sidik jari jika sidik jari sudah terekam pengguna dapat menggunakan jarinya untuk membuka pintu. Jika verifikasi tidak diterima, maka user melakukan registrasi ulang pada admin.

Rancangan proses sidik jari yaitu sidik jari pengguna didaftarkan menggunakan Sensior C3 untuk melakukan verifikasi input sidik jari, dari Sensor C3 diteruskan ke mikrokontroler pada saat itu sidik jari yang sama pada saat perekaman atau accepted, kemudian solenoid akan terbuka jika sidik jari tidak diterima pengguna kembali menginput sidik jari.

Dalam penelitian ini komponen yang digunakan adalah rangkaian beberapa perangkat elektronik yang dipadukan dengan aplikasi Matlab. Walaupun Ide Arduino merupakan bawaan aplikasi yang mudah untuk digunakan untuk programer pemula. Walaupun demikian diperlukan ketelitian dengan urutan penulisan suatu program yang berada dalam aplikasi Ide Arduino seperti halnya aplikasi pemrograman yang lain juga memerlukan urutan yang sistematis. Penulis tidak menggunakan software lain dari program aplikasi Matlab meskipun dapat menyertakan Arduino, seperti: $\mathrm{C}++$ (C), Borland atau Visual Basic. Alat dan bahan yang digunakan dapat dilihat pada tabel 1. Apakah ada pengamatan khusus dalam menjalankan proyek kelompok dan keterampilan manajemen proyek?

Perancangan diawali dengan registrasi sidik jari pada sensor C3 yang diteruskan ke mikrokontroler. Registrasi dilakukan dengan menempelkan sidik jari sebanyak dua kali, registrasi 
pertama akan diverifikasi oleh mikrokontroler dan registrasi kedua akan diverifikasi oleh mikrokontroler yang kedua setiap registrasi dan verifikasi akan ditampilkan oleh I2C. Pencocokan database sidik jari yang telah tersimpan di mikrokontroler akan disesuaikan dengan program Arduino IDE. Jika admin atau pengguna akan membuka pintu, sidik jari dapat ditempatkan pada sensor untuk membuka pintu. Ketika sidik jari diletakkan pada sensor C3, inputnya adalah gambar sidik jari yang dicocokkan dengan database sidik jari jika cocok dengan database, maka solenoid akan terbuka.

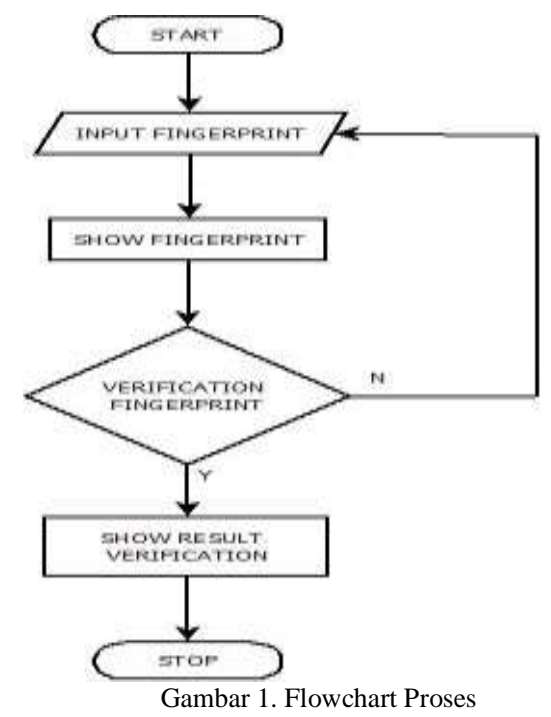

Perancangan verifikasi sidik jari pada aplikasi MATLAB seperti pada gambar 1 adalah sidik jari yang telah disimpan akan diverifikasi dengan memasukkan citra sidik jari ke dalam aplikasi MATLAB. Gambar akan ditampilkan sesuai dengan gambar sidik jari yang dipilih dalam database, gambar sidik jari akan diverifikasi dan ditampilkan sesuai dengan data yang dipilih.

Table 1. Peralatan Sensor Sidik Jari.

\begin{tabular}{|c|c|c|}
\hline No & Nama & Keterangan \\
\hline 1. & Microcontroller & $\begin{array}{l}\text { Arduino } \\
\text { ATMega } 2560\end{array}$ \\
\hline 2. & Motor DC & Selenoid \\
\hline 3. & RTC & $\begin{array}{l}\text { Data Logger SD } \\
\text { Card }\end{array}$ \\
\hline 4. & $\mathrm{I} 2 \mathrm{C}$ & $\begin{array}{l}16 \times 02 \text { Serial } \\
\text { LCD }\end{array}$ \\
\hline 5. & Sensor Sidik Jari & $\mathrm{C} 3$ \\
\hline 6. & $\begin{array}{l}\text { Sumber Daya } \\
\text { Adaptor }\end{array}$ & 5 Volt \\
\hline
\end{tabular}

\subsection{Microcontroller}

Merupakan terobosan teknologi mikrokomputer yang digunakan untuk menangani aplikasi tertentu. Perbedaan mikrokontroler dan mikrokomputer terletak pada RAM dan ROM. Pada komputer memiliki RAM dan ROM yang besar sedangkan pada mikrokontroler RAM dan ROM terbatas. Mikrokontroler terdiri dari ALU (Arithmetic Logical Unit), CU (Control Unit), PC (Program Counter), SP (Stack Pointer), register dan waktu [1].

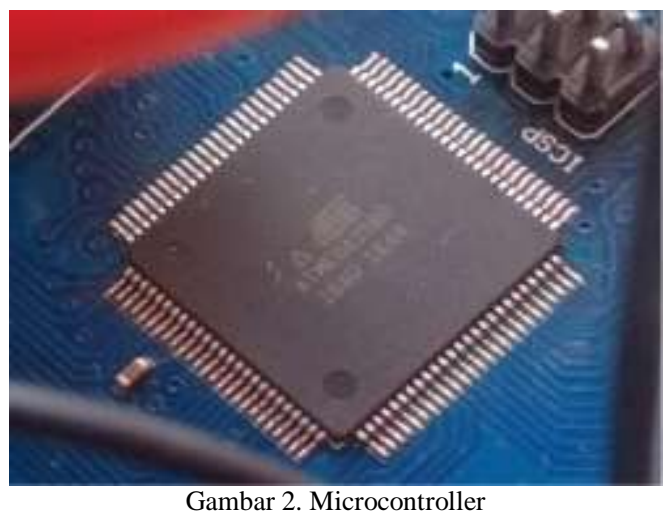

Mikrokontroler adalah sebuah chip yang membuat otak dari rangkaian elektronika. Dengan kata lain, jika otak utama komputer adalah chip prosesor Intel Core i7 (atau AMD) yang dapat mengatur semua perangkat keras mulai dari motherboard, RAM, hard drive, monitor, keyboard, dll, maka rangkaian mikrokontroler ATmega328 adalah otaknya, yang dapat mengatur komponen lain yang terhubung. Jika pada komputer dan software diinstal dengan Sistem Operasi Windows (atau Mac OSX/Linux) sebagai host-nya, software mikrokontroler tersebut berupa program yang langsung dibakar pada chip mikrokontroler yang bersangkutan, dengan bootloader sebagai host-nya seperti yang terdapat pada gambar 2 .

\subsection{Motor DC (Selenoid)}

Solenoid bekerja sebagai pengunci dan akan aktif bila diberi tegangan $12 \mathrm{~V}$. Di dalam solenoida ada kawat melingkar pada inti besi. Ketika arus listrik mengalir melalui kawat, terjadi medan magnet untuk menghasilkan energi yang akan menarik inti besi [7].

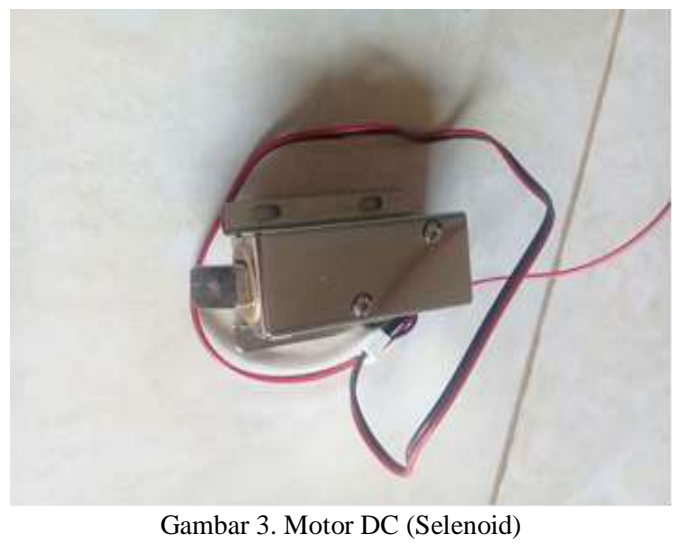


Solenoid Door Lock adalah salah satu solenoida yang digunakan khusus sebagai solenoida untuk kunci pintu secara elektronik. Solenoid ini memiliki dua sistem kerja, NC adalah Normaly Close dan NO adalah Normaly Open seperti yang terdapat pada gambar 3 .

\subsection{Data Logger Shield}

Data logger dipasok dengan sumber arus $12 \mathrm{~V}$, untuk mengoperasikan data logger diperlukan konfigurasi software terlebih dahulu. Ide Arduino digunakan untuk Pemrograman mikrokontroler [8].

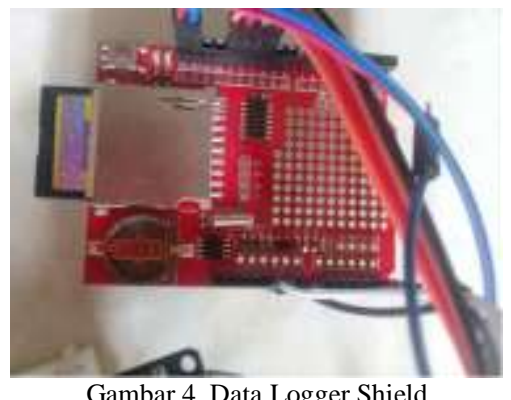

Jenis pelindung data logger adalah RTC DS1307. RTC jika melakukan pembelian baru baik berupa Chip DS1307, Module DS1307, atau Shield Data Logging Shield for Arduino Uno. Sebagian besar produk telah dijual tanpa batery RTC atau tidak terpasang Batteray RTC. Agar RTC DS1307 fungsinya seperti seharusnya kita melakukan setting awal waktu atau Date yang akan di jalankan seperti yang terdapat pada gambar 4.

\subsection{I2C (Inter Integrated Circuit)}

Standar komunikasi serial dua arah menggunakan dua saluran yang dirancang khusus untuk mengirim atau menerima data. I2C dirancang oleh Philips pada awal 1980-an untuk memfasilitasi komunikasi antar komponen dalam satu rangkaian. Awalnya kecepatan komunikasi maksimum 100 kbps karena kecepatan tinggi tidak diperlukan. Pada tahun 1998 dibutuhkan kecepatan tinggi, sehingga ada mode kecepatan 3.4Mbps. I2C dapat digunakan untuk menghubungkan komponen yang terhubung melalui kabel. Fitur utama dari I2C terletak pada bentuknya yang sederhana. Fitur bus I2C adalah [9]:
a) Memiliki 2 baris dan kabel.
b) Pada bus $\mathrm{I} 2 \mathrm{C}$ tidak ada aturan baud rate yang signifikan.
c) Setiap komponen yang terhubung ke bus memiliki alamat yang berbeda.
d) Pengendali jalur komunikasi utama dengan mengatur jam dan menentukan komunikasi user.
e) Proses pengontrolan LCD
f) Pendukungan protokol Arduino

g) Port I2c terletak pada pin A4 untuk jalur SDA (Serial Data)

h) Pin A5 untuk Jalur SCL (Serial Clock)

i) Penghubungan Ground antara Arduino dengan perangkat I2C client

j) Dapat menggunakan Seri maupun paralel

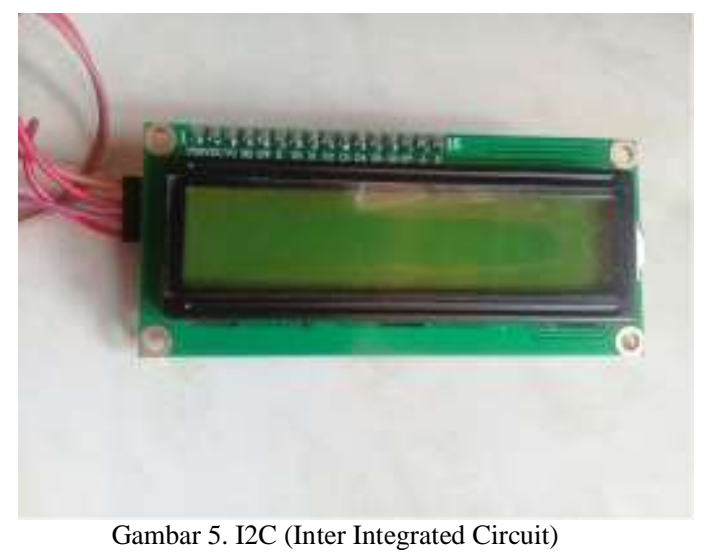

Pada gambar 5. I2C merupakan sistem bus data pilihan yang sering digunakan, sistem pengenalan yang telah dilengkapi dengan komponen pengontrol yang digunakan untuk melayani pertukaran data antar komponen Hardware yang satu dengan komponen Hardware lainnya. Pada sistem mikrokontroler ini terdapat Data bus, Address bus, dan beberapa pengenalan controller. Semakin tinggi frekuensi clock prosesor, semakin berhati-hati pengembang untuk memperhatikan waktu semua komponen yang terlibat, untuk menghindari kesalahan dalam data transaksi. Bus yang sering digunakan adalah bus paralel.

\subsection{Sensor C3}

Sesuai dengan karakteristik Sensor berfungsi untuk mengetahui kinerja dari sensor yang dirancang. Adapun ciri-ciri sifat statik suatu sensor adalah [10]:

\section{Akurasi}

Untuk mengetahui ketidakakuratan suatu sensor, seperti perbedaan nilai perhitungan dengan nilai percobaan.

2. Nonlinieritas

Digunakan untuk sensor yang memiliki fungsi transfer pendekatan linier. Non linieritas juga merupakan aproksimasi maksimum dan dapat dilakukan untuk sensor dengan fungsi transfer non-linier yang dapat digunakan dengan titik terminal dan metode transfer.

3. Saturasi

Setiap sensor memiliki batas operasi meskipun memiliki fungsi transfer linier tetapi pada input tertentu memiliki transfer non linier.

4. Resolusi

Ini adalah kemampuan sensor untuk mendeteksi sinyal input minimum. Ketika 
sensor diumpankan terus menerus, sinyal out put pada sensor tidak akan menghasilkan hasil yang sempurna. Dengan kondisi seperti itu biasanya terjadi perubahan out put, maka sensor dikatakan memiliki resolusi yang kecil.

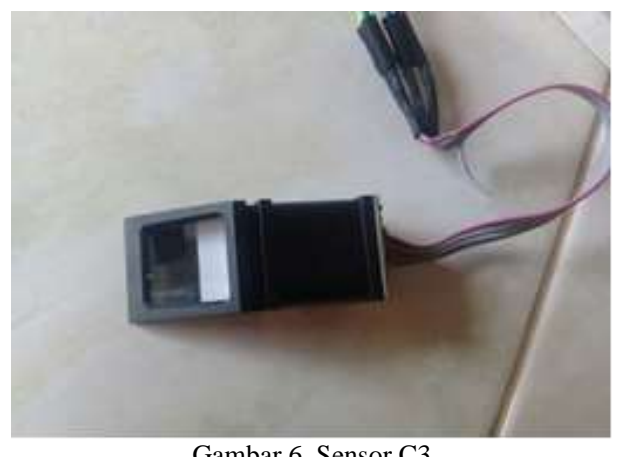

Gambar 6. Sensor C3

Pemindai sidik jari adalah salah satu perangkat elektronik yang paling banyak digunakan untuk menangkap gambar digital dari pola sidik jari. Dengan kata lain gambar tersebut disebut live scanning. Pemindaian langsung adalah pemrosesan digital untuk membuat templat biometrik yang disimpan dan digunakan untuk pencocokan. Ini adalah ikhtisar dari beberapa sidik jari yang lebih umum dan lebih banyak digunakan untuk sensor teknologi seperti yang terdapat pada gambar 6 .

\subsection{Adaptor}

Arus yang berasal dari aliran listrik merupakan arus yang dinamis adaptor mengubahnya menjadi arus searah dan arus yang dihasilkan akan diperkecil sesuai komponen yang digunakan.

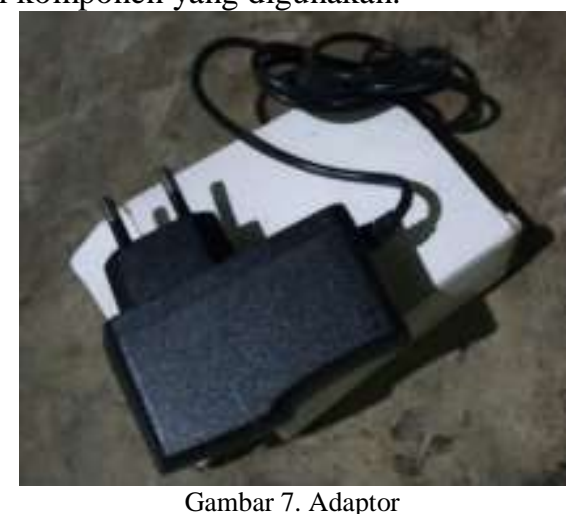

Sumber daya yang dihasilkan adaptor yaitu dapat mengubah arus searah (direck current) dan arus bolak balik (AC). Perusahaan Listrik Negara (PLN) menghasilkan arus kuat dan arusnya bolak balik sedangkan semua alat elektronika menggunakan arus lemah dan searah/rata dan adaptor menggantikan posisi baterai maupun aki pada radio, televisi, tape recorder, amplifier, komputer, dan lainnya. Dengan menggunakan adaptor berarti mengurangi pemborosan biaya dan lebih hemat. Bagian penstabil tegangan: berfungsi menstabilkan tegangan yang dihasilkan sehingga benar-benar mendekati tegangan/arus yang dihasilkan baterai atau aki. Pada bagian output berfungsi mengeluarkan teganganyang dihasilkan adaptor ke Sumber daya adaptor adalah alat yang dapat mengubah arus searah (direct current) seperti yang terdapat pada gambar7.

\section{Hasil dan Pembahasan}

Dari perancangan sistem yang telah dibuat memastikan sidik jari yang telah terdaftar pada input yang teridentifikasi akan diverifikasi menggunakan program aplikasi MATLAB dengan metode Neural Network. Proses verifikasi dilakukan dengan menempelkan jari pada permukaan sensor C3 yang dilanjutkan dengan proses verifikasi sidik jari yang diterima dan akan dibandingkan dengan citra sidik jari pada database. Kemungkinan yang terjadi ketika sidik jari telah berhasil diambil sebagai hasil verifikasinya berhasil atau gagal.

\subsection{Percobaan Peralatan}

Penggunaan software bawaan dari Arduino karena fungsinya yang sederhana dan user friendly dengan komponen yang digunakan dalam penelitian. Pengujian software Arduino IDE dilakukan dengan memasukkan tampilan awal listing program sebagai syarat komponen Arduino dapat dibaca oleh komputer dan Arduino akan terhubung dengan komputer dengan sumber yang digunakan pada Arduino IDE. Pertama, isikan listing program atau sketsa yang ditujukan pada sensor C3 agar sensor C3 dapat terbaca oleh Arduino IDE. Listing program kedua ditujukan untuk LCD I2C (Inter-Integrated Circuit Liquid Crystal Display), sehingga I2C dapat membaca listing program yang digunakan pada Arduino IDE dan dapat menunjukkan apakah sidik jari diterima atau tidak oleh Arduino IDE. Tahap selanjutnya adalah pembuatan listing program pada relay sehingga dapat dibaca oleh Arduino IDE dan dapat bekerja jika ada arus yang masuk maka relay akan memutuskan pin positif dan negatif sebaliknya jika relay tidak menerima arus, relai akan menghubungkan pin positif dan negatif.

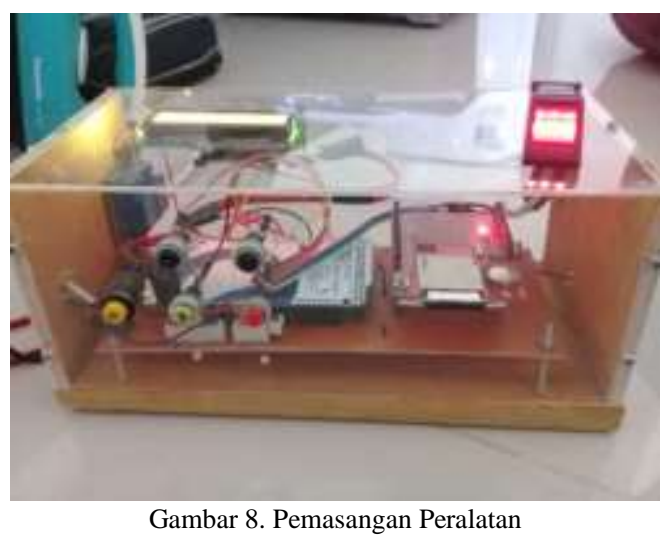


Pengujian komponen Arduino seperti yang ditunjukkan pada Gambar 8 menjadi salah satu tujuan dalam penelitian. Langkah pertama yang dilakukan adalah menghubungkan sensor C3 dengan 4 pin yang terdapat pada Arduino, I2C terhubung ke board Arduino baik terminal positif maupun terminal negatif, relay yang terhubung dengan data logger shield diteruskan ke komponen Arduino. Sebelum sensor digunakan dalam pengujian terlebih dahulu masukkan arus ke Arduino Uno ATMega 2560 dengan daya 5-12 Volt dan cabut kabel USB dari PC karena mikrokontroler telah menyimpan data yang diberikan. Sistem ini akan mencocokkan database sidik jari yang telah disimpan dalam program Arduino IDE dengan cara sidik jari ditempatkan pada sensor untuk membuka pintu. Ketika ada sidik jari yang ditempatkan pada sensor sidik jari maka input berupa sidik jari akan dicocokkan dengan database yang telah disimpan, jika sidik jari tidak sesuai dengan database maka solenoid tidak akan terbuka. Setelah verifikasi sidik jari sesuai dengan database, solenoid akan terbuka dengan durasi 10 detik.

\subsection{Verifikasi sidik jari menggunakan Matlab}

Dari perancangan sistem yang telah dibuat memastikan sidik jari yang telah terdaftar pada input yang teridentifikasi akan diverifikasi menggunakan program aplikasi MATLAB dengan metode Neural Network. Proses verifikasi dilakukan dengan menempelkan jari pada permukaan sensor C3 yang dilanjutkan dengan proses verifikasi sidik jari yang diterima dan akan dibandingkan dengan citra sidik jari pada database. Kemungkinan yang terjadi ketika sidik jari telah berhasil diambil sebagai hasil verifikasinya berhasil atau gagal.

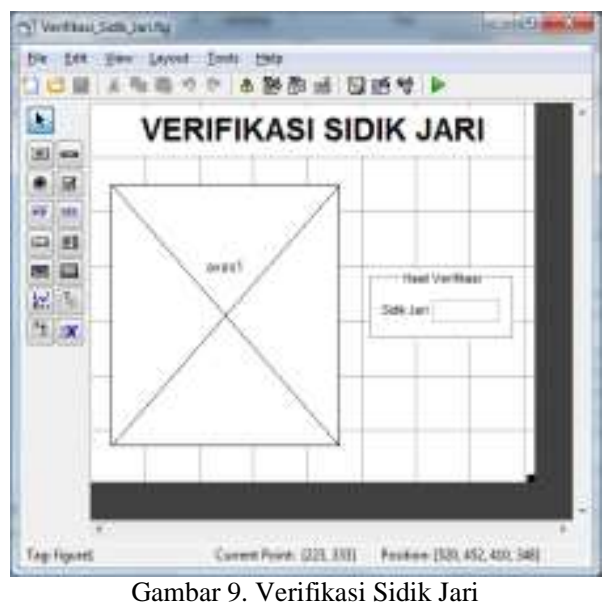

Penggunaan GUI (Graphical User Interface) seperti terlihat pada Gambar 9 pada perancangan verifikasi sidik jari akan mencari sidik jari yang telah digunakan oleh pengguna. Dalam hal ini program aplikasi MATLAB akan mencari data yang telah digunakan. Rancang dengan menekan tombol Menu lalu pilih Open. Setelah gambar muncul, menu Process digunakan dan pilih Neural Network, sistem akan mencari data sidik jari.

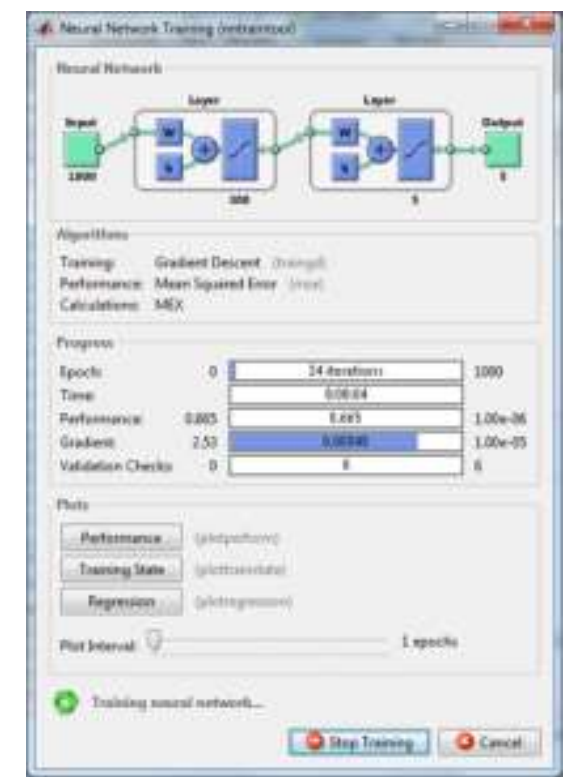

Gambar 10. Percobaan Menggunakan Neural Network

Proses training yang dilakukan seperti terlihat pada gambar 9 menggunakan parameter input 1800 dengan jumlah 2 layer, layer pertama memiliki hidden layer sebanyak 300, layer kedua memiliki hidden layer sebanyak 5 dan proses training menampilkan jumlah output. dari 5. Gambar 10. menjelaskan bahwa proses pelatihan memiliki nilai epoch 1000 dengan jumlah 24 iterasi dan nilai performansi nilai gradien 0,665 sebesar 2,53 dan nilai Validasi sebesar 0. Pada training error goal (MSE) ini sebesar 0,055494 dicapai pada zaman ke24 seperti yang ditunjukkan pada Gambar 11 di bawah ini:

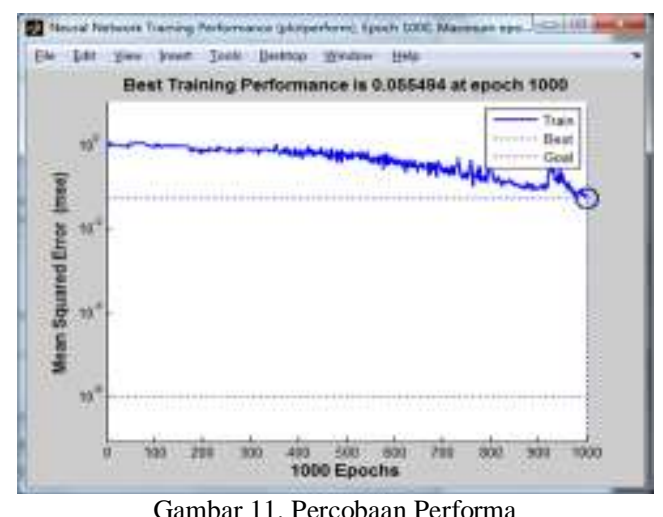

Gambar 11 menunjukkan grafik nilai MSE (Mean Squared Error). Grafik ditampilkan dengan menekan tombol performance yang ditunjukkan pada Gambar 12. Sedangkan tampilan dari training plot dapat dilihat pada Gambar 13 . 


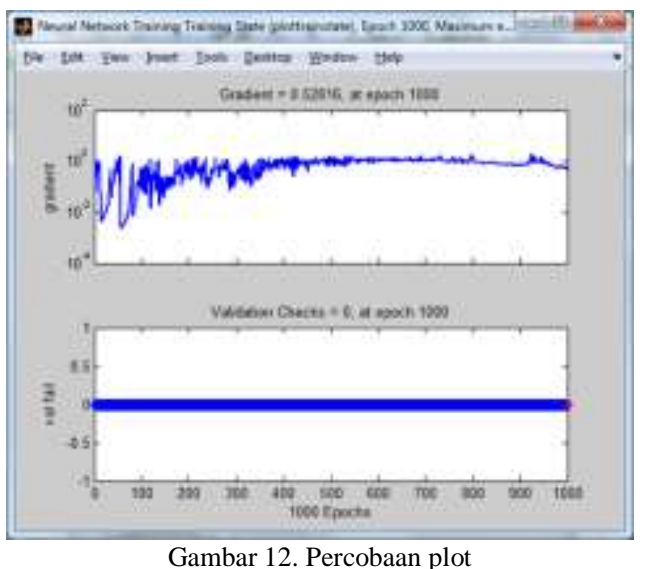

Gambar 12 adalah tampilan plot pelatihan. Tracking plot diperoleh dengan menekan tombol training state pada Gambar 10. Proses training dengan jumlah epoch 1000 dapat menghasilkan nilai gradien sebesar 0,52816 dan nilai validasi cek sebesar 0. Sedangkan koefisien korelasi R sebesar 0,81806 seperti terlihat pada Gambar 12 .

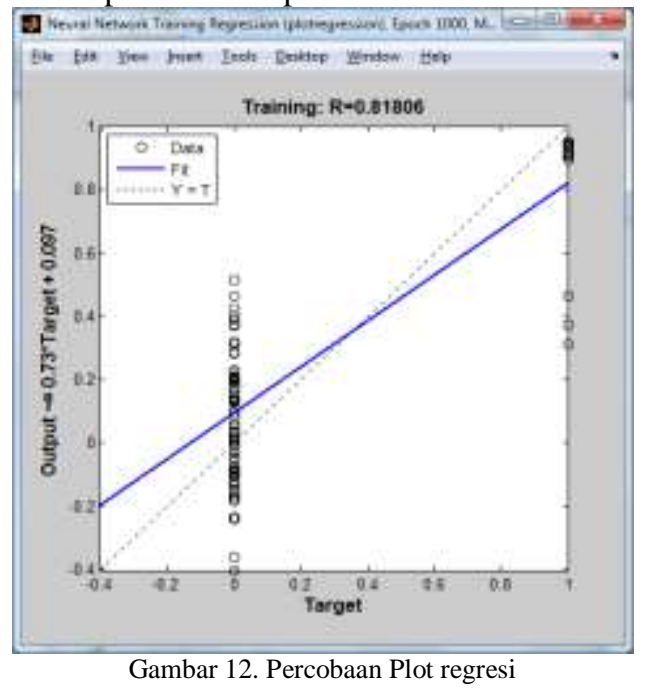

Gambar 12. merupakan tampilan plot regresi dengan menekan tombol Regression pada Gambar 10 .

\section{Kesimpulan}

Percobaan aplikasi Matlab pada peralatan pengaman sidik jari telah berhasil dilakukan dengan kesimpulan bahwa sistem dapat diterapkan pada komponen Arduino sebagai peralaytan pengaman dengan pola sidik jari dan verifikasi yang dilakukan menggunakan aplikasi MATLAB dengan metode Neural Network telah berjalan dengan baik.

\section{Daftar Pustaka}

[1] H. Muchtar and A. Hidayat, "Wavecom Implementation In Microcontroller Based Power Transmission Monitoring," Jurtek UMJ, p. 2, 2017. O. V. Mazurin and E. A. Porai-
Koshits (eds.), Phase Separation in Glass (North-Holland, Amsterdam, 1984) p. 21.

[2] Alfien S, Rintjap. Sherwin. (2014). Aplikasi Absensi Siswa Menggunakan Sidik Jari di Sekolah Menengah Atas Negeri 9 Manado. ejurnal Teknik Elektro dan Komputer. D. L. Eaten, US Patent 3, 904422 (1975).

[3] Anton Yudhana, Sunardi. Jafri Din. (2010). Turtle Hearing Capability Based On ABR Signal Assesment. Telkomnika, 8, 187.

[4] Tole Sutikno, Anton Yudhana. Didi Siprian. (2006). Pengaturan Sakelar Pada Acara Cepat Tepat Berbasis Mikrokontroler AT89C2051. Telkomnika, 4, 185-192.J. Park, J. K. Oh, K. W. Kwon, Y. H. Kim, S. S. Jo, J. K. Lee, and S. W. Ryu, IEEE Photonics Technol. Lett., 20, 321 (2008).

[5] Annisa Ainur, Janatin Hastuti. Zaenuri Sabta N. (2010). Pola Sidik Jari Anak-Anak Normal di SD Budi Mulia Dua Yogyakarta. JKKI.D. C. Look and J. R. Sizelove, Phys. Rev. Lett., 82, 1237 (1999).

[6] Yogie El Anwar, Noer Soejarwanto. Ageng, S. (2015). Prototype Penggerak Pintu Pagar Otomatis Berbasis Arduino Uno ATmega 328P Dengan Sensor Sidik Jari. Electrician.

[7] Helmi Guntoro, Yoyo, S. Erik, H. (2013). Rancang Bangun Magnetic Door Lock Menggunakan Keypad Dan Solenoid Berbasis Mikrokontroler Arduino Uno. Electrans, 41.

[8] Pratama Johansah Endaryono, Harianto. Madha , C. (2014). Rancang Bangun Sistem Pembayaran Mandiri Pada Wahana Permainan. Jcones, 72.

[9] Andi Setiono, Prabowo, P. Bambang, W. (2010). Pembuatan Dan Uji Coba Data Logger Berbasis Mikrokontroler Atmega32 Untuk Monitoring Pergeseran Tanah. Jurnal Fisika, 87.

[10] Fraden, Jacob. (2003). Handbook of Modern Sensor. California: Springer. 